\title{
Financial Literacy, Entrepreneurs Motivation, and Industrial Environment to Increase of SMEs Performance with a Competitive Strategy as Mediator: Theoritical Review
}

\author{
Kenyo Puspito Rini and Iramani \\ Department of Management, STIE Perbanas Surabaya, Surabaya \\ e-mail:kenyopuspitorini@gmail.com
}

\begin{abstract}
SMEs or small and medium enterprises currently have a very important position not only in employment, and the welfare of the community in the region, in many cases SMEs can stabilize the problem of social inequality. Therefore, SMEs are required to have good performance. There is a basic theory about financial literacy theory that argues that the behavior of people with a high level of financial literacy might depend on the prevalence of the two thinking styles according to dual-process theories: intuition and cognition. This study aims to examine the influence of financial literacy, entrepreneur's motivation, industrial environment, and competitive strategy on the performance of small and medium enterprises. By classifying the result of previous research, this research found some propositions: (1) financial literacy has a significant effect on the performance of SMEs (2) entrepreneur's motivation significantly influences the performance of SMEs (3) industrial environment significantly influences the competitive strategy (4) competitive strategies significantly influence SME performance (5) industrial environment significantly influences the performance of SMEs. This study using Partial Least Square (PLS) technique to analyze the data. The proposition as the result studies can be investigated empirically.
\end{abstract}

Keywords-SMEs Performance, Financial Literacy, Entrepreneur's Motivation, Industrial Environment, Competitive Strategy.

\section{INTRODUCTION}

$\mathrm{S}$ ME's or small and medium businesses currently have a very important position not only in employment, and the welfare of the community in the region, in many cases SMEs become the glue and stabilize the problem of social inequality. The Asian Development Bank (2001) says that the role of SMEs is important for industrial restructuring, because SMEs contribute to the growth of employment at a higher pace than large companies, and in the long run SMEs can provide a significant portion of overall employment. The empowerment of SMEs needs to be increased by the Government considering that each year the target of economic growth is higher but not followed by improving the quality of SMEs. The growth of SMEs in the current globalization and high competition makes SMEs have to face global challenges such as increasing product and service innovation, developing human resources, technology and expanding marketing areas. Indonesia's economic market has the potential to develop rapidly because the population will continue to grow so that the demand for supply and demand will also be high. This should be used by SMEs to increase the selling value of SMEs themselves, especially to compete with foreign products that are increasingly flooding the local market. Seeing the many challenges in the future make SMEs as much as possible to develop their businesses.

In practice, SMEs still experience some problems. One of the problems in the management side of SMEs is the weak implementation of accounting. As it is understood that the existence of accounting is very beneficial for SMEs because it is a tool that can help business decision making. In addition, accounting information is also useful in order to prepare various projections, for example, projecting future cash needs, controlling costs, measuring and increasing productivity and providing support for the production process.

The issue of motivation is needed in all respects, including SME entrepreneurs. SME entrepreneurs must continue to raise their motivation to keep running on the specified track. When starting a business until the company is still small in scale, successful entrepreneurs are those who have strong needs for achievement. Rapid changes in technology must be addressed by SMEs by finding alternatives to maintain a competitive advantage by applying new growth processes and methods. Technology has an important role in improving the production process. However, if the growth of this technology is not followed by changes in the quality of existing human resources, it will hamper the performance process of SMEs.

Research conducted by Chepngetich (2016) shows that there is a positive influence between financial literacy on SME performance. Subsequent research on financial literacy carried out by Lusimbo and Muturi (2016) and Iramani et.al. (2018) showed a similar result in that there was a positive influence between financial literacy on SME performance.

In the research Nyang'au et.al. (2014) showed that there was a significant positive effect between entrepreneurial motivation on SME performance. Subsequent research conducted by Aftan and Hanapi (2018) showed the same results, there was a significant positive effect between entrepreneurial motivation on the performance of SMEs.

Research by Hajar et.al. (2012) shows that the results of the industrial environment have a negative and significant effect on organizational capability and company performance and competitive strategy have a positive and significant effect on company performance. Research by Ekaputri et.al. (2018) shows that the industrial environment plays a role in company performance. 
The $1^{\text {st }}$ International Conference on Business and Engineering Management (IConBEM)

February $1^{\text {st }} 2020$, Institut Teknologi Sepuluh Nopember, Surabaya, Indonesia

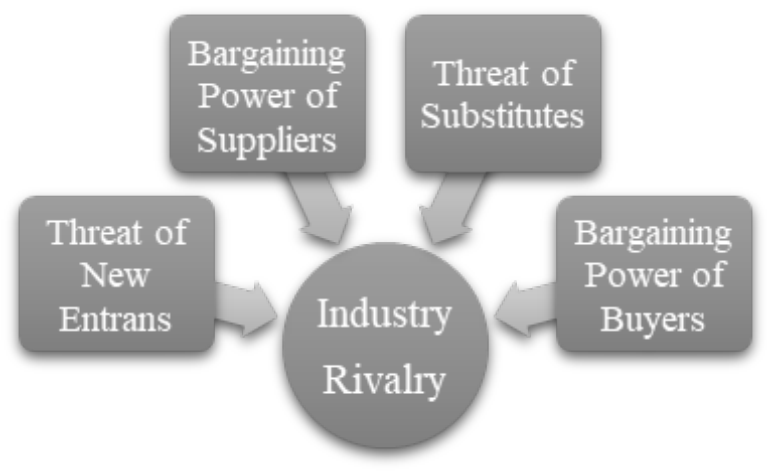

Figure 1. Five Forces Model

Research Uchegbulam et.al. (2015) showed that there was a positive influence between the competitive strategy and the performance of SMEs. Subsequent research conducted by Kowo et.al. (2018) shows that there is a positive influence between the competitive strategy and the performance of SMEs.

\section{THEORETICAL REVIEW}

\section{A. SMEs Performance}

Business performance or growth can be measured both quantitatively and qualitatively. According to Gupta et.al. in Lusimbo (2016), quantitative company performance can be measured by adding value, increasing revenue, total assets, business volume. Whereas qualitatively the company's performance can be measured through the market position and the quality of the products produced.

Performance is generally used for some or all actions of a company in a certain period. Performance, in particular, can be interpreted as determining certain measures that can measure the success of a business in generating profits. Besides, performance improvement reflects how managers or business owners run their business processes. So it can be concluded that the better the performance of the company, the better the business processes of the business in producing quality products.

\section{B. Financial Literacy}

Financial literacy according to Lusardi \& Mitchaell in Yushita (2017), can be interpreted as financial knowledge that has a goal to achieve prosperity. The definition of financial literacy according to Mason \& Wilson in Krishna (2010) is a person's ability to obtain, understand, and evaluate information that is relevant for decision making by understanding the financial consequences it causes. Meanwhile, the Financial Services Authority (OJK) states that literacy is defined as the ability to understand, so financial literacy is the ability to manage the funds owned to develop and live more prosperously in the future. OJK states that the important mission of the financial literacy program is to carry out education in the field of finance to the people of Indonesia to manage finances intelligently so that the low level of knowledge about the financial industry can be overcome and the public is not easily fooled into investment products that offer high returns in the short term without considering the risks.

To ensure public understanding of the products and services offered by financial service institutions, the national financial literacy strategy program has four main pillars, namely:

1. Well literate $(21.84 \%)$ has knowledge and beliefs about financial institutions and financial service products, benefits and risks, rights and obligations related to financial products and services and has skills in using financial products and services.

2. Sufficient literate $(75.69 \%)$, has knowledge and beliefs about financial services institutions and financial products and services, benefits and risks, rights and obligations related to financial service products.

3. Less literate $(2.06 \%)$ only knows financial service institutions, financial products, and services.

4. Not literate $(0.41 \%)$, do not have the knowledge and confidence of financial service institutions and financial services, and do not have the skills in using financial products and services.

\section{Entrepreneurs Motivation}

Successful entrepreneurs with high N Ach (Need for Achievement) will provide guidelines for self-analysis. Ach is an important sign of entrepreneurial drive. Entrepreneurial motivation arises because there is a desire to excel. The more convinced the meaning of his achievement, the more convinced that achievement must be able to push for even better achievement.

In entrepreneurship, motivation requires fighting power to succeed, want to learn to see the success of others, have a strong drive to overcome all obstacles in entrepreneurship. McClelland in Sumarsono (2010) said that the main psychological motivator that motivates entrepreneurs is the need for achievement, which is usually identified as Ach Ach needs are defined as the desire or impulse in people who motivate behavior toward achieving goals.

\section{Industrial Environment}

The industrial environment according to Solihin (2009) is an environment that has a direct influence on the success of a company because the company has direct interaction with the factors that are around it, these factors include the entry of new competitors, suppliers, buyers, availability of substitute products, and competitors competitive. Porter created a conceptual framework of the five forces model that would later assist managers in analyzing the industrial environment.

Porter (1985) proposes a five forces model as a tool to analyze the industrial competition environment, with the scheme in Figure 1.

According to this model, a company to survive and successfully compete with other companies must pay attention to competitive forces, including:

1. Risk of entry of potential competitors, potential competitors are none other than companies that currently do not compete in the industrial world, but he can do so if they wish. The entry of new competitors will potentially reduce the profits of existing companies, because they may not ask for high prices for the products that will be offered.

2. Bargaining power of suppliers, suppliers have different bargaining positions on the company. The ability of a supplier to determine trading conditions that are favorable to him and less profitable for the company or 
The $1^{\text {st }}$ International Conference on Business and Engineering Management (IConBEM)

February $1^{\text {st }} 2020$, Institut Teknologi Sepuluh Nopember, Surabaya, Indonesia

create trading conditions that benefit both parties will affect the performance of the company. If the company can obtain a supply of raw materials from several suppliers, the company's position is relatively stronger than suppliers, so that suppliers do not pose a significant threat to the company.

3. Bargaining power of buyers, what is meant by industrial buyers are individual customers (final buyers) and companies that manage these products (B2B). The bargaining power of buyers is the ability of buyers to bargain prices from companies in the industry to a lower level or to increase company costs by accepting good quality and service for their products.

4. Threats of substitute products, competition for products produced by companies not only come from companies that produce the same product so that it gives a direct competition effect, but can also be seen from companies that produce products with similar functions to the products produced by the company.

5. Competition between companies that exist, in the industry there is always competition between companies with other companies. The intensity of competition between companies in the industry is strongly influenced by industrial growth factors, the inability to produce orders, the products produced are the same, and the prices produced are quite high.

\section{E. Competitive Strategy}

A strategy is defined as the main pattern of action chosen to realize the vision of the organization through the mission. The strategy forms the pattern of decision making in realizing the organization's vision. A strategy is a tool to create a competitive advantage.

In analyzing the strategy requires a SWOT analysis which is the systematic identification of various factors to formulate the company's strategy. This analysis is based on the logic that can maximize strengths, weaknesses, opportunities, and threats that exist in the business [1]. Some of these theories indicate that the strategy is comprehensive covering all important aspects of the company and is integrated into that all parts of the planning need to be well integrated.

\section{METHOD}

This paper is conceptual and qualitative. It started from various previous studies related to the performance of SMEs. Several previous studies have explained the influence of financial literacy, entrepreneurial motivation, industrial environment and competitive strategies used in this study with SME performance.

\section{RESULT AND DISCUSSION}

Based on the theoretical foundation and previous research and the problems that have been raised, as a basis for formulating a hypothesis, a framework of thought can be presented in the model in the Figure 2.

\section{A. Effect of Financial Literacy in SMEs Performance.}

Some empirical studies that explain the positive effects of financial literacy on business performance are described as follows. Lusimbo and Muturi (2016) research results revealed that although SME managers knew financial literacy, most did not understand the effect of inflation and interest rates on loans they borrowed and did not compare terms and conditions before buying financial products, most managers had book literacy The low one. The study also concluded that the majority of SMEs in the study area did not keep business records which could enable them to accurately measure the financial performance of their business due to lack of knowledge and skills possessed. The results of this study indicate a positive relationship between financial literacy and company performance. Furthermore, the results of Chepngetich's research (2016) show that financial literacy has a positive and significant effect on SME performance. Expertise in managing and recording budgets and keeping records of expenditure plans for the availability of funds can increase future growth and overall SME performance. Research Iramani et.al. (2018) show a similar result, namely financial literacy has a positive effect on the performance of SMEs.

\section{B. Effect of Entrepreneurs Motivation in SMEs Performance.}

In improving company performance, entrepreneurs need motivation. Motivation is a factor that can influence someone to act in the direction of a particular goal. In entrepreneurship, an individual certainly has its motivation. Motivation determines outcomes such as Grant's productivity, performance, and perseverance in Lamsah (2018). The high growth rate of SMEs is also influenced by the high level of entrepreneurial motivation. On the other hand, the government must be more active in supporting entrepreneurs.

\section{Effect of Industrial Environment in SMEs Performance.}

The industrial environment is a set of threat factors from new businesses, suppliers, buyers, substitute products, and the intensity of competition among competitors that directly affect the company and its competitive actions and responses. The industrial environment creates uncertainty, therefore planning and strategy are needed to be able to maintain good performance. The results of the study of Hajar et.al. (2012) showed that the industrial environment harmed company performance. That is, the less dynamic the industrial environment, the higher the performance. While the results of the study by Ekaputri et.al. (2018) show that the industrial environment plays a role in company performance.

\section{Effect of Industrial Environment in Competitive Strategy.}

The environment creates uncertainty for managers, and they must respond to this uncertainty by planning so that the organization can adapt. To survive in the face of similar competition and an ever-changing industry environment, a company needs an appropriate strategy. The point of formulating a competitive strategy is connecting the company with its environment. Although the relevant environment is very broad encompassing, social forces as well as economic forces, the main aspect of the corporate environment is the industry or industries in which the company competes.

The structure of the industry has a strong influence in determining the rules of the competitive game as well as strategies that are potentially available to companies. The results of the study of Hajar et.al. (2012) industrial environment had a negative and not significant effect on 
The $1^{\text {st }}$ International Conference on Business and Engineering Management (IConBEM)

February $1^{\text {st }} 2020$, Institut Teknologi Sepuluh Nopember, Surabaya, Indonesia

competitive strategies. That is, the more dynamic the industrial environment, the more incompatible competitive strategies are formulated and implemented.

\section{E. Effect of Competitive Strategy in SMEs Performance.}

A competitive strategy is the setting of a company's longterm goals and objectives and the direction of action and allocation of resources needed to achieve certain goals and objectives. A competitive strategy is an effort to find a profitable competitive position in an industry, a fundamental arena where the competition takes place. The competitive strategy aims to foster a favorable and strong position against the forces that determine the competition in the industry [2]. The right competitive strategy is needed by the company to produce better performance. Research by Hajar et.al. (2012) shows that competitive strategy has a positive effect on firm performance. This means that the more competitive the strategy is formulated and implemented, the higher the company's performance will be in the small industry. The research results of Uchegbulam et.al. (2015) and Kowo et.al.
(2018) stated the same thing, there was a positive influence between the competitive strategy on the performance of SMEs.

\section{LIMITATIONS}

The lack of papers about some of the variables used by researchers makes the depth of discussion rather limited.

\section{RECOMMENDATION}

The results of the conceptual framework in this study can be used and tested empirically for further research related to company performance, especially in the SME sector.

\section{REFERENCES}

[1] F. Rangkuti, Analisis SWOT Teknik Membedah Kasus Bisnis. Jakarta: Gramedia Pustaka Utama, 2004.

[2] M. E. Porter, Competitive Strategy: Techniques for Analyzing Industries and Competitors. New York: The Free Press, 1980. 